\title{
Appropriation and Educational Uses of Mobile Phones by Students and Teachers at a Public University in Mexico
}

\author{
Javier Organista-Sandoval ${ }^{1}$, Arturo Serrano-Santoyo ${ }^{2}$ \\ ${ }^{1}$ Instituto de Investigación y Desarrollo Educativo, UABC, Ensenada, México \\ ${ }^{2}$ Centro de Inv. Científica y de Educación Superior de Ensenada, CICESE, Ensenada, México \\ Email: javor@uabc.edu.mx, serrano@cicese.edu.mx
}

Received 28 March 2014; revised 25 April 2014; accepted 10 May 2014

Copyright (C) 2014 by authors and Scientific Research Publishing Inc.

This work is licensed under the Creative Commons Attribution International License (CC BY).

http://creativecommons.org/licenses/by/4.0/

(c) (i) Open Access

\begin{abstract}
This article presents a study on appropriation and educational uses of cell phones. For the research, a random sample of 954 students and 246 teachers was selected, representing respectively $12 \%$ and $24 \%$ of the total population in two facilities of UABC in Ensenada, Mexico. Our survey showed that $97 \%$ of teachers or students have some kind of cell phone or smartphone. However, we observed that one of every four interactions with the mobile device had a concrete educational purpose. We also found that in general the educational use of the cell phone is mainly aimed to establish communication between the students and to access information via Internet. However, in spite of its limitations, our results show that the cell phone is a technological tool with great pedagogical potential. We suggest that institutional policies are necessary in order to tap that the cell phone potential to adequately support the teaching-learning process.
\end{abstract}

\section{Keywords}

Technology Integration, Educational Trends

\section{Introduction}

The recent technological advances of mobile communications and ubiquitous computing have propitiated the development of a highly convergent portable device with important technological and ergonomic features that allow spontaneity of use and high speed connectivity (Sharples, Taylor, \& Vavoula, 2007; Naismith, Lonsdale, Vavoula, \& Sharples, 2009). These capabilities have influenced the acceptance and adoption of mobile technology by society, particularly in academic environments. 
We will start our contribution discussing the concept of appropriation. According to Jones \& Issroff (2007), appropriation is seen as a process in which specific devices are adopted, molded and utilized. This perspective involves both the technical skills regarding the use of the mobile device and its integration to the user's daily activities. Based on this perspective, the purpose of our article is to describe the ownership distribution and the appropriation patterns of mobile phones for a segment of the academic community of the Autonomous University of Baja California (UABC) in Mexico. We also present the observations of students and teachers on the main advantages and disadvantages of mobile phone usage. Our findings indicate that mobile phones might be significant educational tools due to the wide spectrum of potential applications they offer. However, it is important to point out that it is necessary to carry out formal and rigorous studies to accomplish the proper insertion of mobile devices in the educational context.

This article is organized as follows: in Section 2 we describe the basic framework of our contribution, related work and literature review. In Section 3 we present our research method including elements of the context and a brief discussion of the survey for both, the students and teachers. Our main results are described in Section 4, and Sections 5 and 6 include respectively discussion and conclusions of our findings about mobile phone usage for educational purposes at UABC.

\section{Framework}

According to data presented by Canalys Research (Cooper, 2012), more mobile phones than computers were sold in 2011. Mobile phones have become essential tools in everyday life. Given their capabilities for access to information in ubiquitous and immediate fashion, a variety of effects in all areas of knowledge are expected (Kukulska-Hulme, 2009).

According to Brown (2005), the individual learning process mediated by portable devices is associated with the user's skills for information management, understanding and practical knowledge of the devices' capabilities. Success in this process is accomplished when users are able to address contextualized problems of their daily lives, to communicate the information and knowledge they have found and to collaborate with other individuals in this learning process.

The technological features of mobile phones have attracted the interest of the international academic community to investigate their educational potential (Sharples, Taylor, \& Vavoula, 2007). Thus, a growing number of papers from the educational technology perspective have been published showing experiences and discussing the pedagogical applications of such devices.

For the case of Mexico, the National Institute of Geography and Statistics (INEGI) reported in 2013 that around 50\% of Mexican citizens have internet access with a mobile line penetration of 97 million (84\% of the total mobile market). These figures indicate the importance of these technologies in the Mexican population, particularly among the young segment.

Related research on the mobile phone usage among Mexican students and teachers is presented as follows. Crovi, Garay, Lópezy Portillo (2011) show the levels of usage and appropriation of mobile phones among students in three Mexican public universities. These authors find that the process of appropriation (understood as incorporation and cultural transformation) is not balanced neither systematic. They highlight the need for developing digital skills on the part of the academic stakeholders in order to function openly and fairly in the current cultural environment.

Aguilar-Barceló and Ramírez-Angulo (2007) argue that the level of penetration and expenditure on mobile phone usage will depend largely on the income, technology skills and gender of students. An interesting approach of Ramírez (2008) and Herrera, Lozano, \& Ramírez (2008) suggests that portable devices do not substitute a learning instrument or environment; moreover, they offer additional resources for supporting teaching and learning. Treviño and Millán (2007) discuss a special application of mobile devices to allowing young students to keep contact with relatives when visiting the insecure regions of the Tamaulipas state of Mexico.

It is convenient to point out that in our literature review we frequently found positive experiences regarding the use of Information and Communications Technologies (ICT) in the higher education institutions of Mexico. However, it was difficult to find instances regarding problematic situations or issues about technology applications in educational contexts in Mexico.

Based on the reviewed literature, the purpose of this paper is to describe the appropriation of mobile phones among students and teachers in two campuses of UABC in Ensenada, Mexico. We also describe the main edu- 
cational applications and the major limitations of such devices.

\section{Method}

We used a quantitative-descriptive methodology. In order to show our main findings, we draw on the control of the variables associated with the academic community, particularly with those variables regarding the ownership and usage of mobile phone applications with respect to the appropriation level and educational use of such devices at UABC. Our subject of study was the Bachelor degree students and teachers of two campuses of UABC.

Academic Context: The Ensenada Campus consists of two academic facilities in the Ensenada urban area, denoted as Valle Dorado and El Sauzal. The Valle Dorado campus has twice as many students compared with El Sauzal. El Sauzal is mainly oriented to physical sciences and engineering, while Valle Dorado is mostly oriented to social sciences and humanities.

Participants. Out of the total student population (9008) reported at http://csege.uabc.mx in 2011, we selected a random representative sample of size (n) employed by Cuesta \& Herrero (2010). Using this approach, we obtained an estimated sample size for the student population was 954 considering the following values $[\mathrm{N}=9008$; $\mathrm{Z}=1.96 ; P=0.5 ; \mathrm{e}=0.03$ ]. Such sample size represents $10.5 \%$ of the total population enrolled in both campuses. Regarding the teachers, we estimated that 1046 work in the several job categories of the university (full time, half time and outsourced academic personnel). The sample size for the teachers was 246 [N = 1046; $\mathrm{Z}=1.96 ; P$ $=0.7$; e $=0.05]$. Such sample size represents $24 \%$ of the total population. Based on the above figures, we randomly selected the participants in order to obtain a representative sample of the community under study (see Table 1).

As regards gender, the proportion of women and men is fairly balanced for both students and teachers. The students' average age was 21.3 years, which corresponds to the typical age of university students in the location under study. The teachers' average age was 43.3 years with high dispersion values (10.8). See Table 2.

Survey of ownership and mobile phone usage. We structured two questionnaires, one for students and one for teachers. These questionnaires were designed with three basic axes: Communication, information management and organization of activities mediated by mobile phones. (See Figure 1 and Appendix 1)

Each survey consisted of 60 items, 40 of which were measured in the ordinal scale, 4 in the nominal scale (free text), 5 nominal-dichotomous, 4 in the ratio scale and 7 in the nominal-categorical scale. The surveys were organized in the following four chapters:

1) General information of participants. We included age, gender, school of enrollment, morning or evening shift, starting date of mobile phone usage and attitude and behavior regarding mobile phone usage. The items were similar for students and teachers, except in those cases regarding the working condition of teachers.

2) Technology Aspects: Mobile phone ownership information, connectivity matters, type of mobile phone contract and basic technical features. For this case the items were similar for both students and teachers.

3) Mobile phone applications usage. Information about the applications, frequency and educational intention of use. The surveys for students and teachers were different due to the respective activities these two groups.

4) Advantages and disadvantages. This chapter focuses on the participants opinion, we included questions regarding the benefits and limitations of mobile phone usage.

When the Cronbach's alpha coefficient is estimated for two sections of the survey (attitude toward mobile phone usage (6 items) and mobile phone frequency of usage (20 items)), the obtained values show adequate consistency (see Table 3).

Application. The intervention with students and teachers was held during the first semester of 2011, the surveys were applied randomly. We requested the teachers' authorization to apply the survey in the classrooms. For the teachers' case, the surveys were conducted at the administration desk area. The survey took a month for students and three months for teachers.

\section{Results}

\subsection{Students and Teachers Ownership of Mobile Phones at UABC}

Ownership distribution data of some type of mobile phone is shown in Table 4. It can be seen that $96 \%$ of students and $97 \%$ of teachers have at least one mobile phone. We found significant differences among students (contrast $\mathrm{X}^{2}$, significance 0.01 ) regarding ownership levels when comparing freshman and senior populations. 
Table 1. Sample size of selected students and teachers.

\begin{tabular}{ccccc}
\hline & Population & \multicolumn{2}{c}{ Sample size } \\
\cline { 2 - 4 } & $\mathbf{N}$ & $\mathbf{n}$ & $\%$ \\
\hline Students & 9008 & 1073 & 11.9 \\
Teachers & 1046 & 247 & 23.6 \\
\hline
\end{tabular}

Table 2. Gender distribution and average age of students and teachers.

\begin{tabular}{|c|c|c|c|c|c|c|}
\hline & \multicolumn{2}{|c|}{ Female } & \multicolumn{2}{|c|}{ Male } & \multicolumn{2}{|c|}{ Age } \\
\hline & $\mathbf{n}$ & $\%$ & $\mathbf{n}$ & $\%$ & Mean & SD* \\
\hline Students & 562 & 52.5 & 509 & 47.5 & 21.3 & 3.8 \\
\hline Teachers & 125 & 50.6 & 122 & 49.4 & 43.3 & 10.8 \\
\hline
\end{tabular}

*SD refers to standard deviation.

Table 3. Cronbach's Alpha for two sections of the survey.

\begin{tabular}{ccc}
\hline & Attitude (6 items) & Application usage (20 items) \\
Students & 0.81 & 0.90 \\
Teachers & 0.79 & 0.92 \\
\hline
\end{tabular}

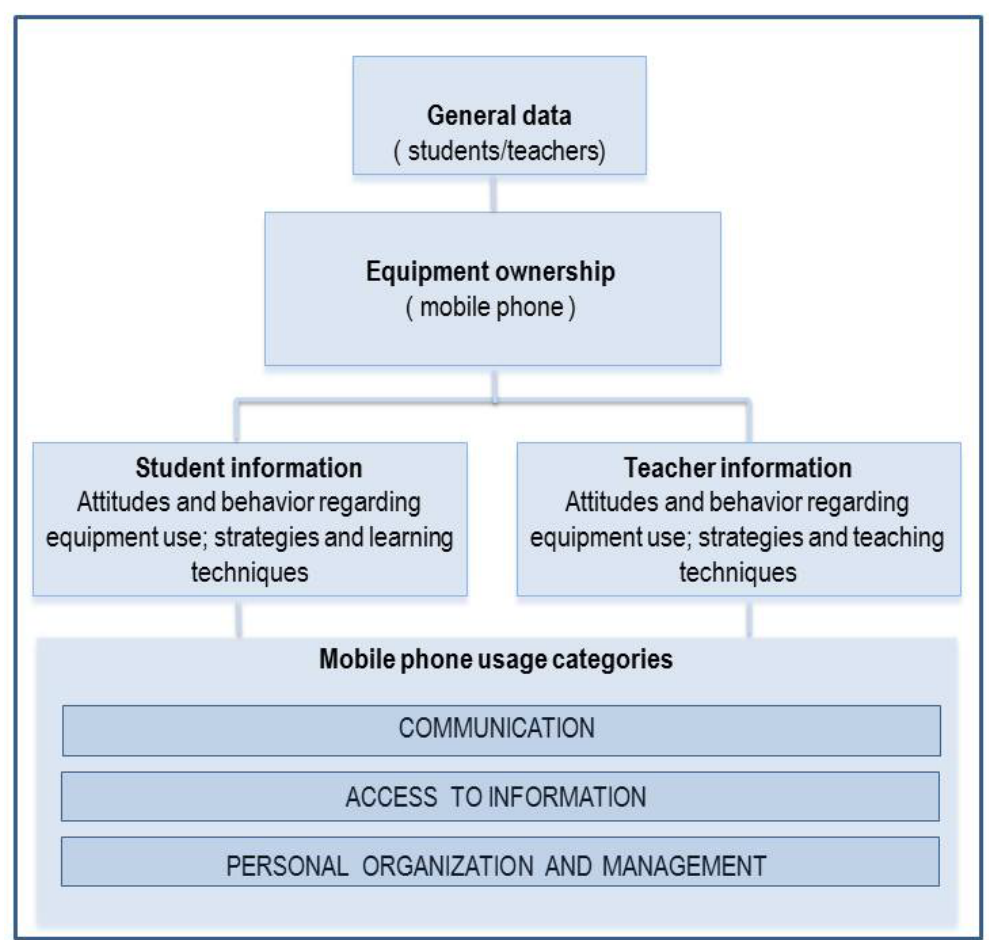

Figure 1. Basic elements for the students and teachers surveys.

We did not find significant ownership differences among teachers regarding the type of mobile service provider contracts or academic degree.

In order to differentiate smartphones from conventional mobile phones, we consider as smartphones those devices with Wi-Fi capabilities and 3G/4G features. Hence, based on the ownership distribution shown in Table 4, we estimated that $53 \%$ of students and $63 \%$ of teachers own some type of smartphone.

\subsection{Self-Concept on the Usage of Mobile Phones}

An interesting aspect of our research was to exploring the associated variables with respect to the personal opi- 
nion on the usage of mobile phones. Table 5 shows the average values of the variables employed: Starting date of mobile phone usage (years), self-evaluation of technical skills, readiness od mobile phone usage and personal disposition for educational usage of mobile phones. According to the scale value of the respective variable, we applied statistical contrast i-student for independent samples and U-Mann-Whitney. We found significant differences in all comparisons $(P<0.005)$. The teachers showed longer periods of ownership and better personal opinion indicators regarding mobile phone usage. They also showed better disposition for using mobile phones for educational instances.

Based on the associated variables, we may infer that both students and teachers have an intermediate level of mobile phone adoption.

\subsection{Use of Mobile Phone Applications}

We estimated the mobile phone daily usage for students and teachers and their respective differences (see Table 6). The applications mostly used for both students and teachers were short text messaging (SMS) and voice calls. It is worth noting that the major differences correspond to the students' entertainment applications. In the teachers' case, the major differences correspond to e-mail, management of contacts and voice calling application.

We show in Figure 2 the average level of importance that students and teachers place on specific educational activities mediated by mobile phones. The students indicated that information downloads and help requests are the most important activities. The teachers indicated that management of time and contacts are their most important activities. In general, students place more weight than teachers on the mobile phone as an educational tool.

\subsection{Advantages and Disadvantages of Mobile Phones}

The main disadvantages of mobile phone usage for both students and teachers were: distraction caused by phone use, the excessive emphasis on non-educational matters and the high connectivity costs. Regarding the main educational usage of mobile phones, both the students and teachers pointed out the importance of immediate and ubiquitous communication and information access. One aspect highlighted by students was the great potential of "apps" to accomplish educational tasks providing access to a wide spectrum of programs to support their learning process.

\section{Discussion}

We would like to point out that the sample size obtained for both students and teachers is representative of the population under study. This sample size exceeds the minimum suggested by the algorithm employed. Hence, our results show an adequate level of representativeness and can be therefore generalized for the academic community of UABC as a whole.

Table 4. Ownership distribution of mobile phones for students and teachers at UABC.

\begin{tabular}{|c|c|c|c|c|}
\hline & \multicolumn{2}{|c|}{ With mob. phones } & \multicolumn{2}{|c|}{ Without mob. phones } \\
\hline & $\mathbf{n}$ & $\%$ & $\mathbf{n}$ & $\%$ \\
\hline Students & 1025 & 96.0 & 42 & 4.0 \\
\hline Teachers & 240 & 96.8 & 8 & 3.2 \\
\hline
\end{tabular}

Table 5. Associated variables for mobile phone usage and appropriation.

\begin{tabular}{|c|c|c|c|c|c|}
\hline & \multicolumn{2}{|c|}{ Students } & \multicolumn{2}{|c|}{ Teachers } & \multirow[b]{2}{*}{$\boldsymbol{P}$} \\
\hline & Mean & SD & Mean & SD & \\
\hline Years using mobile phone & 6.7 & 2.8 & 10.5 & 4.0 & $0.000(\mathrm{t})$ \\
\hline Self-evaluation of personal technology skills ${ }^{*}$ & 2.0 & 0.6 & 2.3 & 0.6 & $0.000(\mathrm{U})$ \\
\hline Readiness for mobile phone usage ${ }^{* *}$ & 2.4 & 0.7 & 2.2 & 0.7 & $0.000(\mathrm{U})$ \\
\hline Disposition for educational usage of mobile phones ${ }^{* * *}$ & 2.0 & 0.6 & 1.9 & 0.5 & $0.027(\mathrm{U})$ \\
\hline
\end{tabular}

${ }^{*}$ Scale 0 - 3: 0: not familiar, 1: beginner, 2: intermediate, 3: advanced; ${ }^{* *}$ Scale 0 - 3: 0 : very difficult, 1 : difficult, 2 : easy, 3: very easy; ${ }^{* * *}$ Scale 0 - 3: 0 : strongly disagree, 1: disagree, 2: agree, 3: Strongly agree. 
Table 6. Percentage differences in mobile phone applications usage between students and teachers.

\begin{tabular}{cccc}
\hline Applications & Students $(\mathbf{S})$ & Teachers $\mathbf{( T )}$ & \% Differences \\
\cline { 2 - 4 } Music reproduction & \% & \% ] & 38.1 \\
Games/entertainment & 73.6 & 35.5 & 24.3 \\
Video reproduction & 43.9 & 19.6 & 13.2 \\
Social networking & 40.2 & 27.0 & 12.2 \\
Video recording & 42.1 & 29.9 & 6.1 \\
Picture management & 30.3 & 24.2 & 4.5 \\
Information search & 59.0 & 54.5 & 3.2 \\
Notes edition & 42.0 & 38.8 & 2.9 \\
Audio recording & 35.7 & 32.8 & 1.8 \\
Dictionaries and translation & 22.6 & 20.8 & 1.6 \\
Text edition & 17.8 & 16.2 & 0.6 \\
Videoconference software & 17.1 & 16.5 & 0.3 \\
SMS & 20.5 & 20.2 & 0.0 \\
Internet surfing & 100.0 & 100.0 & -3.5 \\
PDF reading & 35.7 & 39.2 & -5.6 \\
Calculator & 16.6 & 22.2 & -5.8 \\
Calendar and agenda & 46.6 & 52.4 & -7.6 \\
Voice calling & 59.1 & 66.7 & -13.9 \\
Contact management & 85.1 & 99.0 & -14.0 \\
E-mail & 75.6 & 89.6 & -17.9 \\
\hline
\end{tabular}

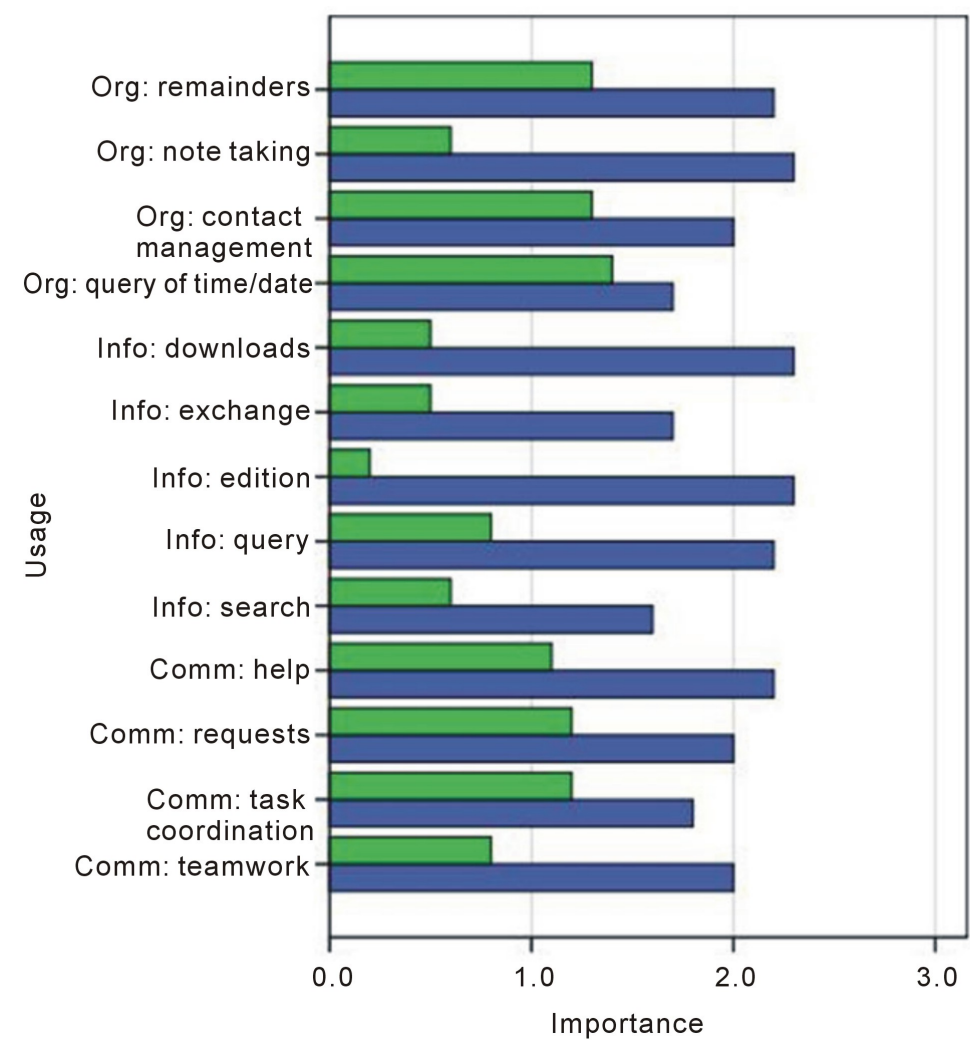

Students

Figure 2. Main use and importance of mobile phone usage from students and teachers opinion (scale $0-3$; where 3 is the most important). 
It is worth noting that the academic community under study showed ownership of $97 \%$ of at least one mobile phone. Out of this percentage, $50 \%$ corresponds to smartphones. These data suggests favorable conditions for harnessing the pedagogical potential of these devices. The challenge is to increase the pace and magnitude of educational applications mediated by such technology.

Regarding the associated variables of mobile phone usage, we obtained results that show an average ownership span of 7 years. This result implies a student mobile phone usage from practically pre-youth stage. This span for the teachers' case was of 11 years. We point out that students showed a higher degree of readiness of mobile phone usage, which according with Duart et al. (2008), this may suggest an impact on the students' creativity linking her or his learning environment and activities to Internet use.

The applications with higher degree of use for the students were SMS, voice calling and contact management. In order to identify usage trends, we estimated the percentage differences of mobile phone usage between students and teachers. Thus, the major differences on the students' side were music reproduction, gaming, social networking (mainly Facebook). The teachers were in favor of e-mail, contact management and voice calling.

These results show that mobile phone usage among students brings the possibility for distraction, but at the same time, the potentiality of supporting learning and providing access to information in a ubiquitous and immediate manner.

The participants in our research indicated also some issues and shortcomings of mobile phone usage for educational purposes: High costs of cellular service, short battery life and limitations on screen size and connectivity, among others. Moreover, the students indicated concerns related to prohibitions, restrictions of use and lack of pedagogical strategies for allowing the incorporation of mobile phones to supporting learning in educational contexts. Regarding the benefits of mobile phone usage, both students and teachers pointed out the importance of being connected to friends and colleagues and the ability to accessing information. This finding coincides with results presented in Brown (2005) indicating that mobile learning must be based on immediate communication and access to information capabilities.

From a practical standpoint, the students pointed out other educational applications of mobile phone usage such as picture taking, Internet connectivity, audio and video recording, creation and access to PDF files and interaction with classmates via SMS or voice, among other activities. Other applications related to accessing high capacity data repositories, communication spontaneity, mobility features, social networking and multimedia applications were discussed and highlighted by Aparici (2011).

\section{Conclusion}

The purpose of this paper has been to describe the appropriation of mobile phones among students and teachers in two campuses of UABC in Ensenada, Mexico. Our findings show that in the population under study there is an increasing interest for educational use of mobile phones, however entertainment applications are still prevalent and very significant. This suggests the need for developing more educational applications to counterbalance the pervasive influence of other type of mobile usages. The fast pace of technology development and issues related to connectivity and mobile devices costs face an important challenge for the appropriation of mobile phones. We sensed the need for the establishment of institutional policies that foster the diffusion and adoption of educational tools using mobile devices and at the same time exploring new avenues for a balanced approach to mobile phone usage in the academic contexts. We acknowledge the important pedagogical potential offered by mobile phone usage. However, there are challenges that suggest the need of increasing the spectrum and magnitude of research geared to orienting the efforts and developments of the academic community around pedagogical applications.

\section{References}

Aguilar-Barceló, J. G., \& Ramírez-Angulo, N. (2007). Hábitos de consumo de las tecnologías de información en los estudiantes universitarios de Tijuana. Revista Universitaria de la UABC, 5, 34-40.

Aparici, R. (2011). Principiospedagógicos y comunicacionales de la educación 2.0 Revista Digital la educ@ción, No. 145, 1-14. http://www.educoas.org/portal/La_Educacion_Digital/laeducacion_145/articles/Roberto_Aparici.pdf

Brown, T. (2005). Beyond Constructivism: Exploring Future Learning Paradigms. Education Today, Issue 2, 1-11. http://www.bucks.edu/old docs/academics/facultywebresources/Beyond constructivism.pdf

Cooper, D. (2012). Canalys: More Smartphones than PCs Shipped in 2011. 
http://www.engadget.com/2012/02/03/canalys-more-smartphones-than-pcs-shipped-in-2011/

Crovi, D. D., Garay, C. L. M., López, G. R., \& Portillo, S. M. (2011). Uso y apropiación de la telefonía móvil. Opiniones de jóvenes universitarios de la UNAM, la UACM y la UPN. Revista Derecho a Comunicar, 3, 54-73.

Cuesta, M., \& Herrero, F. J. (2010). Introducción al muestreo. Depto. de Psicología, Universidad de Oviedo. http://www.psico.uniovi.es/Dpto_Psicologia/metodos/tutor.7/

Duart, J. M., Gil, M., Pujol, M., \& Castaño, J. (2008). La universidad en la sociedad red: usos de Internet en educación superior. Barcelona: Editorial Ariel.

Herrera, J. A., Lozano, F. G., \& Ramírez, M. S. (2008). Competencias aplicadas por los alumnos para el uso de dispositivos m-learning. Trabajo presentado en el XVII Encuentro Internacional de Educación a Distancia: virtualizar para educar.Guadalajara, Jalisco.

Jones, A., \& Issroff, K. (2007). Motivation and Mobile Devices: Exploring the Role of Appropriation and Coping Strategies. Alt-f, Research in Learning Technology, 15, 247-258. http://dx.doi.org/10.1080/09687760701673675

Kukulska-Hulme, A. (2009). Will Mobile Learning Change Language Learning? ReCALL, 21, 157-165. http://dx.doi.org/10.1017/S0958344009000202

Naismith, L., Lonsdale, P., Vavoula, G., \& Sharples, M. (2009). Literature Review in Mobile Technologies and Learning (Report no.11). Future Lab Series, University of Birmingham. http://archive.futurelab.org.uk/resources/documents/lit_reviews/Mobile_Review.pdf

Ramírez, M. S. (2008). Dispositivos de mobile learning para ambientes virtuales: Implicaciones en el diseño y la enseñanza. RevistaApertura, 8, 82-96.

Sharples, M., Taylor, J., \& Vavoula, G. (2007). A Theory of Learning for the Mobile Age. In R. Andrews, \& C. Haythornthwaite (Eds.), The SAGE Handbook of E-Learning Research (pp. 221-247). Thousand oaks, California: SAGE.

Treviño, E. F., \& Millán, O. A. (2007). La influencia de la telefonía celular en el entorno social de los jóvenes universitarios en Tampico Tamaulipas (México). Trabajo presentado en el Foro Internacional sobre Comunicación e Xuventude. Galicia, España. 


\section{Appendix 1}

Universidad Autónoma de Baja California, Instituto de Investigación y Desarrollo Educativo, Mobile phone usage survey, STUDENTS

Purposes. This survey compiles information on the educational use of mobile phones. The information provided is strictly confidential. We appreciate your collaboration.

Instructions. Please read carefully. Questions with multiple options should be marked with X according with your best opinion.

\section{General Data}

Age []

Gender: [] Female [] Male

Major: [] Semester: []

English language skills:

\begin{tabular}{llll}
\hline [] Null & [] Beginner & [] Intermediate & [] Advanced \\
\hline
\end{tabular}

What's your grade point average? []

Do you have internet connectivity in your home? [] Yes [] No

What's your personal experience with technology?

[] Not familiar (I have never used or rarely used a computer)

[] Beginner (Basic email management, Word, web browsing, but I require frequently help

[] Intermediate (I currently use advanced applications, rarely request help)

[] Advanced (Computer science skills).

Best personal assessment. Select your preferred learning experience (just one):

[] Problem solving strategies

[] Discovery learning strategies

[] Interacting with computer programs

[] Communicating with others

[] Through frequent instructor guidance

Select your preferred learning technique (just one):

[] Repetition and memorizing

[] Summarizing, underlining, highlighting content

[] keywords; mental maps

[] Using examples and analogies

[] Information classification and organization

[] Using diagrams, graphs, conceptual maps, etc.

[] Inquiring and asking questions

\section{Technological Aspects}

How many mobile phones do you have? []

For each section please indicate the technical feature(s) corresponding to your mobile phone.

\begin{tabular}{ll}
\hline Operating system: & [] \\
Keyboard type: & [] \\
Camera type: & [] \\
Connectivity: & {[]} \\
\hline
\end{tabular}

Please indicate how many times per day you access these applications with your mobile phone. 


\begin{tabular}{cl}
\hline Social networking (Facebook; Twitter; MySpace, etc.) & [] \\
e-mail (Outlook; Thunderbird; Eudora, etc.) & {[]} \\
Videoconferencing (Skype; Live Messenger, etc.) & {[]} \\
Calendar/Agenda & {[]} \\
Calculator & {[]} \\
Contact management & {[]} \\
Note editor & {[]} \\
Web browser (IE; Chrome; Firefox; Safari, Opera Mini) & {[]} \\
Search engines (Google; Yahoo; Bing, etc.) & {[]} \\
Word processor; spreadsheet ( Word, Excel, PP, etc.) & {[]} \\
Dictionary/Translator & {[]} \\
Adobe Reader & {[]} \\
Audio recorder & {[]} \\
Musicplayer (MP3/MP4) & {[]} \\
Video player & {[]} \\
Video recorder & {[]} \\
Picture management & {[]} \\
Voicecalling & {[]} \\
Entertainment/Games & {[]} \\
\hline
\end{tabular}

\section{Student Aspects}

How many years have you used your mobile phone? [] Has it been difficult to use your mobile phone?

\begin{tabular}{llll}
\hline [] verydifficult & [] difficult & [] easy & [] veryeasy \\
\hline
\end{tabular}

which is the option that suits you best for learning with your mobile phone?

\begin{tabular}{cc}
\hline [] Exploring on my own & [] Consulting the manual \\
[] Inquiring an expert & [] Internet searching \\
[] Other. & Which? \\
\hline
\end{tabular}

The mobile phone is a necessary tool in our academic activities.

\begin{tabular}{llll}
\hline [] Strongly disagree & [] disagree & [] agree & [] Strongly agree \\
\hline
\end{tabular}

The mobile phone is an important support for my university studies.

\begin{tabular}{llll}
\hline [] Strongly disagree [] disagree & [] agree & [] Strongly agree \\
\hline
\end{tabular}

I like to use my mobile phone.

\begin{tabular}{llll}
\hline [] Strongly disagree & [] disagree & [] agree & [] Strongly agree \\
\hline
\end{tabular}

I feel motivated to use my mobile phone. 


\begin{tabular}{llll}
\hline [] Strongly disagree & [] disagree & [] agree & [] Strongly agree \\
\hline
\end{tabular}

I always carry my mobile phone.

\begin{tabular}{llll}
\hline [] Strongly disagree & [] disagree & [] agree & [] Strongly agree \\
\hline
\end{tabular}

The mobile phone is an essential element to avoid feeling isolated.

\begin{tabular}{llll}
\hline [] Strongly disagree & [] disagree & [] agree & [] Strongly agree \\
\hline
\end{tabular}

\section{Student-Technology Aspects}

Indicate the three most important communication activities, with educational focus, that you carry out with your mobile phone ( 1 = less important; 2 = important; 3 = most important $)$.

\begin{tabular}{cl}
\hline [] Teamwork & [] Task organization and coordination \\
[] Requesting information & [] Requesting help (classmates/teacher) \\
[] Other. & Which? \\
\hline
\end{tabular}

Indicate the three most important activities regarding information management, with educational focus, that you carry out with your mobile phone ( 1 = less important; 2 = important; 3 = most important $)$.

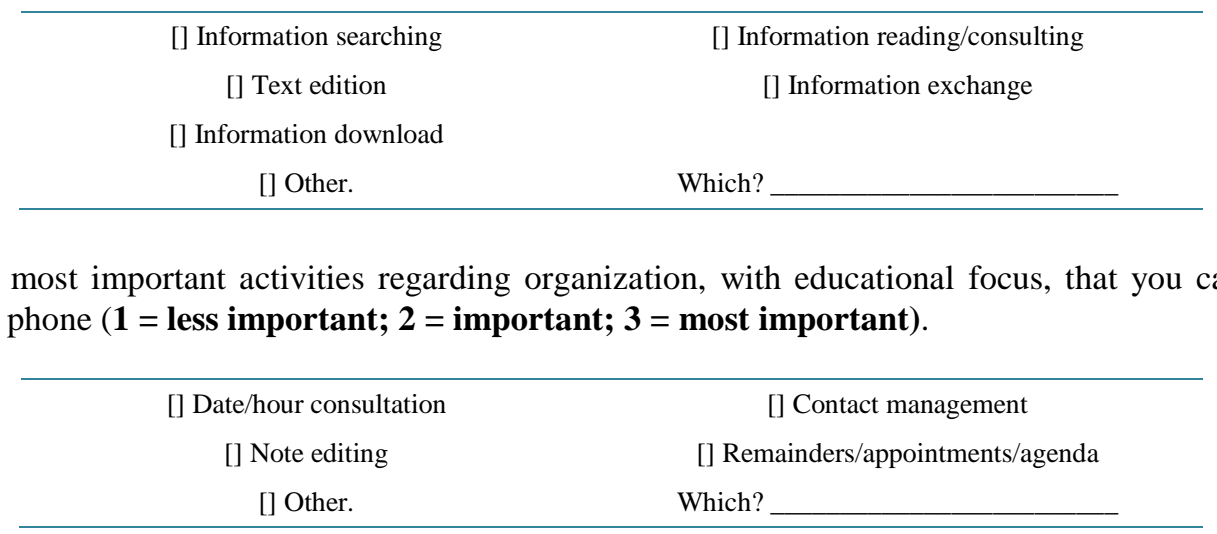

Describe briefly the main advantage of mobile phones to support learning Describe briefly the main disadvantage of mobile phones to support learning 
Scientific Research Publishing (SCIRP) is one of the largest Open Access journal publishers. It is currently publishing more than 200 open access, online, peer-reviewed journals covering a wide range of academic disciplines. SCIRP serves the worldwide academic communities and contributes to the progress and application of science with its publication.

Other selected journals from SCIRP are listed as below. Submit your manuscript to us via either submit@scirp.org or Online Submission Portal.
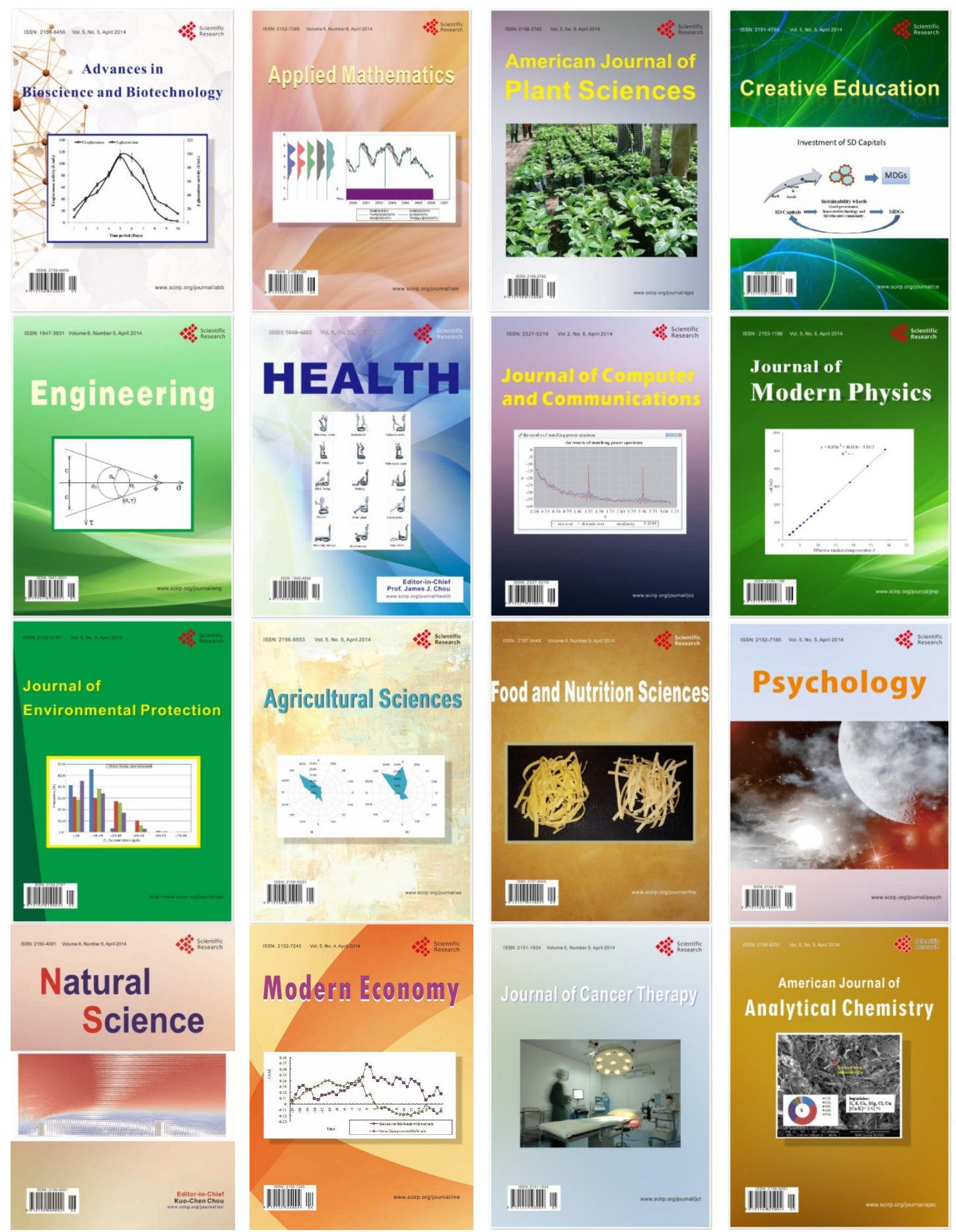